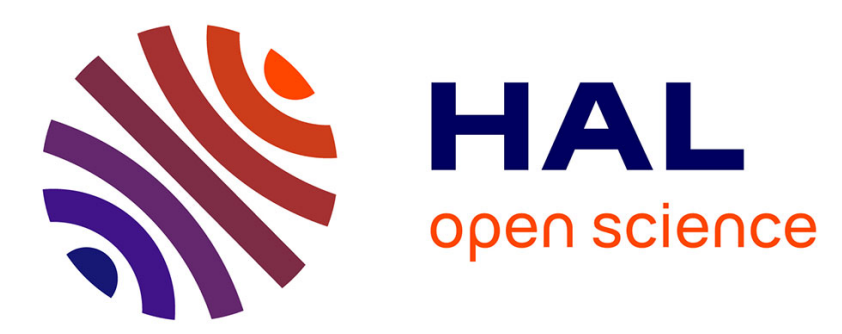

\title{
Price adjustment under the table: Evidence on efficiency-enhancing corruption
}

\author{
Daniel Levy
}

\section{To cite this version:}

Daniel Levy. Price adjustment under the table: Evidence on efficiency-enhancing corruption. European Journal of Political Economy, 2007, 23 (2), pp.423-447. 10.1016/j.ejpoleco.2007.01.001 . hal02387458

\section{HAL Id: hal-02387458 \\ https://hal.science/hal-02387458}

Submitted on 29 Nov 2019

HAL is a multi-disciplinary open access archive for the deposit and dissemination of scientific research documents, whether they are published or not. The documents may come from teaching and research institutions in France or abroad, or from public or private research centers.
L'archive ouverte pluridisciplinaire HAL, est destinée au dépôt et à la diffusion de documents scientifiques de niveau recherche, publiés ou non, émanant des établissements d'enseignement et de recherche français ou étrangers, des laboratoires publics ou privés. 


\title{
Price adjustment under the table: Evidence on efficiency-enhancing corruption
}

\author{
Daniel Levy* \\ Department of Economics, Bar-Ilan University, Ramat-Gan 52900, Israel
}

Final Revision: January 16, 2007

\begin{abstract}
Based on first-hand account, this paper offers evidence on price setting and price adjustment mechanisms that were illegally employed under the Soviet planning and rationing regime. The evidence is anecdotal, and is based on personal experience during the years 1960-1971 in the Republic of Georgia. The description of the social organization of the black markets and other illegal economic activities that I offer depicts the creative and sophisticated ways that were used to confront the shortages created by the inefficient centrally-planned command economic price system with its distorted relative prices. The evidence offers a glimpse of quite explicit microlevel evidence on various types of behavior and corruption that were common in Georgia. Rentseeking behavior, however, led to emergence of remarkably well-functioning and efficiency enhancing black markets. The evidence, thus, underscores once again the role of incentives in a rent-seeking society.
\end{abstract}

JEL Classification: B14; D30; D73; E64; H26; H40; K42; O17; P20; P26; Z13

Key Words: Corruption; Black market; Bribe; Price system; Distorted relative prices; USSR; Command economy

* Tel: +972 3531 8331; Fax: +972 37384034.

Email address: Levyda@mail.biu.ac.il. 


\section{Introduction}

"Science requires more resources of the language than raw sense data and first-order predicate logic... Economics is a science, and a jolly good one, too. But a serious argument in economics will use metaphors and stories as well-not for ornament or teaching alone but for the very science."

Deirdre N. McCloskey (1998, p. 19)

"The tendency of economists to treat statistical studies as automatically more informative than narrative studies has no justification in general and is clearly pernicious in contexts... where the data are so poor."

Steven Durlauf (2001, p. 67)

Although corruption is believed to be a widespread phenomenon (see, for example, Marjit, et al. 2000; Abed and Gupta, 2002; and Foellmi and Oechslin, 2006), direct hard data on corruption and its prevalence is scarce because of its illegal nature. The absence of hard quantitative data on corruption makes it difficult to bring corruption-related debates-and more generally public debates related to unethical behavior-to the forefront of the policy discussion agenda.

Some public institutions and private organizations have been trying to fill this void by producing cross-country indicators of corruption. These indicators have been used in recent empirical studies that explore the economic effects of corruption or the determinants of corruption in cross-sections of countries. Examples of such indicators include the International Country Risk Guide Index (ICRGI) which is published by Political Risk Services, Inc., the Institute for Management Development Index (IMDI), which is included in the World Competitiveness Yearbook, and the Corruption Perception Index (CPI), which is compiled by Transparency International. These indicators are typically constructed using various forms of surveys that include businessmen, political analysts, and general public, and where the respondents are asked to rank order countries based on their perceived level of corruption, the rule of law, risk of contract repudiation, quality of bureaucracy, quality of political, legal, lawenforcement, and judiciary institutions, etc. (Herzfeld and Weiss, 2003). ${ }^{1}$

Given the illegal nature of most forms of corruption, there is little hope of obtaining direct evidence or actual hard quantitative data on corruption from any official government source such as government statistical agencies and other data collection institutions on a large scale. ${ }^{2}$ Although anecdotal evidence about prevalence of corruption abounds, unfortunately such

\footnotetext{
${ }^{1}$ See Méndez and Sepúlveda (2006) for more details on these indexes. Other examples that use these indexes include Mauro (1995, 1997), Gupta, et al. (2001), and Paldam (2002). See also the studies published in the four-volume set on The Politics of Corruption, edited by Williams (2000) and Williams, et al. (2000), which also include several empirical studies.

${ }^{2}$ Recent studies conducted by the economists of the International Monetary Fund and the World Bank, report some quantitative estimates of corruption-related economic activities in some developing and underdeveloped countries. See, for example, the studies by Abed and Gupta (2002) and Reinikka and Svenssen (2001), as well as other studies cited therein.
} 
evidence is rarely published in academic studies. Indeed, only a limited number of published academic studies have offered anecdotal evidence about corruption. The few examples that I was able to locate include Simis (1982), Hillman and Schnytzer (1986), Lambsdorff (1998), Naylor (1998), Gupta, et al. (2001), and Easterly (2001).

A likely reason for the scarcity of anecdotal evidence in academic economic research might be the economists' general lack of enthusiasm about this type of evidence. That is because it is virtually impossibile to falsificfy anecdotal evidence, making such evidence scientifically doubtful. However, there are some well-known exceptions of studies that rely only on anecdotal evidence, although most of these studies are historical in nature. Perhaps the best known example is Radford's (1945) paper on a prisoners' of war (P.O.W) camp. In his paper, Radford offers a fascinating eyewitness account of the economic organization of a P.O.W camp during World War II. According to his account, in the informal and mostly exchange-based markets that developed at the P.O.W camp, cigarettes emerged endogenously as having the role of money and its three functions by serving as a medium of exchange, as a unit of account, and as a store of value. ${ }^{3}$ Radford's paper offers only narrative anecdotal evidence. Nevertheless, the study has never been criticized for this, as far as I know. To the contrary, it is considered a classic study, and it has been widely cited, especially by introductory and intermediate textbook authors. ${ }^{4}$

Recently the economics discipline has been more open to the possibility that anecdotal evidence may fruitfully supplement more standard and more commonly accepted statistical evidence. That is particularly true in cases where data from standard sources are non-existent. For example, Romer and Romer (1989, p. 167) suggest that narrative approach “...allows a vast body of information that cannot be employed in conventional statistical tests, to be brought to bear on...[a] question.” McCloskey $(1990,1998)$ and Durlauf (2001) have also advocated quite forcefully a wider use of anecdotal evidence in economic research. See also the discussions in Jönsson (1993), Lukka and Kasanen (1995), and Zbaracki, et al. (2004, 2006).

In this paper, I offer some direct and quite explicit anecdotal evidence on various types of behavior in the Republic of Georgia during the years 1960-1971. Several existing studies explore the nature of corruption in the former Soviet Union, and attempt to explain it as well as its economic consequences. See, for example, Simes (1975), Simis (1977, 1982), Grossman (1977), Bergson (1984), Hillman and Schnytzer (1986), and Levin and Satarov (2000). ${ }^{5}$

\footnotetext{
${ }^{3}$ In several barter exchange experiments conducted by Fried and Levy (1995) and Levy and Bergen (1993), Mexican dry beans emerged endogenously as playing the role of money. According to their account, the beans were used in transactions as a medium of exchange as well as a unit of account in their classroom, exchange-based market economy.

${ }^{4}$ For other examples of studies that use narrative anecdotal type of evidence, see the collection of readings in Kohler (1968).

${ }^{5}$ For an analysis of corruption in the post-transition Russian Federation, see Levin and Satarov (2000), who offer an interesting discussion of the institutional pathologies in the Soviet economy prior to the collapse of the USSR, pathologies that contributed
} 
In the paper, I tell the story of my family, how we dealt with the constant shortages and inadequate services the official centrally planned markets of Georgia could offer, and how we participated in Georgia's illegal black market economy. As Hillman (2004, p. 1067) notes, "The people who can best describe corruption are those themselves engaged in corruption." Indeed, the evidence I offer is a first hand-account, based on my and my family's actual daily experiences in Georgia.

The paper makes two specific contributions. First, unlike most of the existing studies of corruption, I offer a detailed and fairly rich micro-level narrative account of various types of illegal transactions that were taking place in the corrupt black markets of Georgia as part of routine everyday life. Second, I primarily focus on the unofficial price setting and price adjustment mechanisms used at the black markets. The latter is particularly useful because the price system is the single most important institution in a market based economy.

The evidence on corruption that I document for the Republic of Georgia confirms that, in the absence of free markets, wage and price systems do not reflect true relative prices according to the true market conditions. In such environments, rent-seeking behavior of individuals can lead to a development of black markets where unofficial prices and bribe rates will clear the markets, because the black market prices and quantities respond to changes in market conditions to reflect the true relative valuations.

Before proceeding, I shall note two caveats. First, the evidence I offer here on the corruption in Georgia should not be viewed as representative of corruption in socialist countries in general or even in other republics of the former Soviet Union in particular. The fact is that Georgia was one of the most corrupt, or perhaps even the most corrupt amongst the 15 republics of the former USSR, and it is unclear to what extent and to what depth the various forms of corruption that existed in Georgia's economy also existed in other locations.

Second, although I characterize Georgian corruption as driven primarily by the rigidities of the centralized price system and the rent seeking motives of bribe-maximizing bureaucrats, it should be noted that the corruption in Georgia likely has socio-cultural roots as well. For example, the corruption seems to persist even in contemporary Georgia despite the process of large-scale privatization and other free market reforms implemented by Georgia's current reformminded government. Indeed, as recently as 2003, Georgia's economy was still ranked amongst the top 6 most corrupt economies in the world by Transparency International's CPI.

The paper is organized as follows. In section 2, which constitutes the main body of the 
paper, I provide a narrative anecdotal account of numerous episodes of illegal and corrupt economic transactions and activities in Georgia. In section 3, I offer interpretation of the evidence by asking whether corruption in Georgia was efficient in some sense. In section 4, I discuss ethical and moral aspects of the corruption in Georgia. In section 5, I address the issue of generalizability of the evidence reported in the paper and explore possible explanations to the persistence of corruption in today's Georgia. In section 6, I consider the admissibility and potential benefits of anecdotal evidence for studying corruption. I conclude in section 7 with a brief summary of the findings and some caveats.

\section{Evidence on corruption}

In this section, I offer direct and quite explicit anecdotal evidence on the economic corruption of Georgia's markets and institutions by providing a detailed account of various kinds of illegal economic transactions and activities my siblings were engaged in. While these transactions usually included common types of corrupt activities such as bribe payments, embezzlement, and fraud, unfortunately sometimes also included were dishonest acts of cheating, scams, rip offs, etc. I begin the discussion by offering a brief description of my family background and the town in which we lived, and by providing some general information about the market structure of Georgia's centrally planned economy.

\subsection{Georgia's centralized command market system}

Georgia, like the rest of the 14 republics in the former Soviet Union, did not have a free market economy. Rather, the Georgian economy was a centrally planned command economy. That is, government officials and bureaucrats and the members of the communist party apparatus functionaries made the decisions regarding the products and services to be produced, how much will be produced, and for whom will be the output produced. In western style free market economies, in contrast, market forces along with the flexible price system are the mechanisms that determine the answers to these key questions.

Given that market forces in Georgia were not allowed to function freely, decision-makers such as firms, families, and individuals, had to find ways around the restrictions imposed by the centrally planned totalitarian economic structure, and its inefficient price system. As demonstrated below, if the price and wage systems are not flexible enough to reflect the dynamics of open market forces by adjusting to changes in market conditions, then market

participants have powerful incentives to find alternative mechanisms to overcome the problems and limitations that are caused by these price and wage system inflexibilities. 
In the republics of the former Soviet Union, the wage rate in an organization was set in such a way that it was equal for everyone with the same level of education, experience, etc., and this despite the fact that not everyone was equally productive. Moreover, these wages were set at a very low level. The wages, which at the time were in the range of 30-60 Rubles, could theoretically be sufficient if all goods and services were indeed priced at the official rate. That was not the case, however; 30 Rubles would not cover even one week's expenses on minimal necessities for an average family. That is because to accomplish anything, bribing and sidepayments to government bureaucrats and functionaries, and quite often even to police officers, were necessary. Therefore, in Georgia, the problems created by central planning were resolved, at least in part, by developing a black market, where goods and services were traded at the black market prices that typically included bribe premiums that reflected the true relative valuations of these goods and services.

\subsection{Food chain in black markets}

I was born and raised in Tskhakaya (since Georgia regained its independence from Russia, the town's name has been changed to Senaki), a small town in the western part of Georgia, close to Kutaisi-the regional capital. Three of my brothers worked at government stores, selling various types of clothing, shoes, fabrics, etc. The stores were all located in the local market, called "bazari" in Georgian. The bazari was physically set up as a big circle. In the center of bazari was the fruits and vegetables market, where local farmers from the outskirts of Tskhakaya would sell their wares. Around the circle, along the bazari's walls were scattered various kinds of stores, such as hardware stores, clothing stores, barber shops, book shops, etc., as well as a few restaurants. In addition, there were designated areas for selling milk products, flour and related products, chicken and other meat products, etc.

The stores were all government-owned and operated in a similar fashion. No private ownership was allowed or recognized. All goods and services were produced by government owned factories and manufacturing plants, or imported to Georgia by government import agencies. The prices of the goods and services were set by government officials. For example, the prices the barbers charged were set by government directives. Similarly, the prices of shirts, trousers, shoes, and other goods sold at these stores were also set by government officials. The proceeds from sales were forwarded to the government office. The employees of the shops were paid on a monthly basis by the local government salary payment offices.

One main problem with the system was the inadequate level of the salaries. Therefore, the workers had to find some source of supplementary income. And everyone found some way of 
doing it. For example, the Kolkhoz farmers would sell some of their produce at the bazari at the "free market" price, rather than sending it all to government storage facilities, which paid them a low fixed price, regardless of the quality of the produce. The market price typically was much higher than the government regulators assessed. Therefore, the farmers who sold their produce at the bazari would pocket nice profits. ${ }^{6}$

Although the bazari's existence was legal and authorized, the individuals who came to sell their wares there had to bribe various officials, because otherwise, given the lack of another market, they could be denied entrance to the market, or just be harassed by nosy market officials and policemen. Thus the bazari authorities would happily allow people to bring to the market any legal, border-line legal, or even illegal (e.g., counterfeit) merchandise, as long as they were properly compensated for it. The bribe payments could take various forms, but typically, they would include a side-payment (in addition to the official nominal fee) to the person at the entrance to the market, who exerted much power because he could deny entrance to the merchants or he could report them to the police. Also, there was a limit to the quantity of merchandise the sellers could bring to the market, and bribing the person at the gate was the only way of eliminating that barrier. Various bazari officials and controllers and often the policemen as well would personally go around the merchant tables scattered in the bazari and collect their bribe payments, sometimes in cash but quite often in kind also.

The employees at these shops and stores used various methods to supplement their miserable government-paid salaries, but most often they would inflate the prices of almost everything they were selling, often by as much as 200-300 percent above the official price. However, they could not pocket all the profit. Instead they shared it with the store manager, who shared it with his supervisor, who shared it with the local police station staff, etc. This way, everybody in the "food chain" received his or her share with the implicit understanding that as long as everyone played according to the rules, there was no reason to disrupt this remarkably efficient method of income redistribution.

A model of hierarchically structured corrupt economy with a similar "food chain" element is considered by Hillman and Katz (1987), who use it to study dissipation of rent and revenue in a corrupt economy where, because of bribe and other transfer payments, the social cost of contestability of a rent or revenue encompasses resources used in more than one contest. To motivate their hierarchical structured model, they refer to variety of scenarios that quite resemble the realities we faced in Georgia. Examples include a lowly customs official who is obliged to pay a proportion of his take of bribes to a superior, or a local councilman who is assisting with a

\footnotetext{
${ }^{6}$ Hillman and Schnytzer (1986) and Grossman (1977) also note that this phenomenon existed in the Republic of Georgia.
} 
change in a zoning ordinance and makes further payments within the local government hierarchy to facilitate the rezoning request, etc.

I can offer many such examples from Georgia. For instance, the medical services were supposed to be free. However, to obtain satisfactory medical care, bribes and other types of under-the-table payments in cash or in kind were necessary. For example, when I was about 11 years old, my older brother and I were sent to Tbilisi, the capital of Georgia, to undergo a tonsillectomy, a surgical procedure that was routinely done in those days to every child. When we visited the doctor's office at the hospital, the first thing my brother did was to discreetly hand him an envelope, saying, "Our parents have asked us to give this envelope to you." The envelope contained 300 Rubles. Georgian doctors never refused to accept these kinds of gifts. ${ }^{7}$ Naturally, some part of these gifts likely ended up in the hands of the hospitals' chief doctors and administrators.

Similarly, in order to enter an institute of higher education, payments to the "right people" were absolutely necessary. ${ }^{8}$ Incredibly perhaps, bribing teachers was common even after entering the university. For example, students taking written exams would often put in their examination notebooks some amount (20-30 Rubles perhaps) before handing in their exam notebooks. One of my brothers was able to improve his grades in his high school diploma after haggling (literally!) with his teacher on the price. It turns out that the teacher was asking for 4 Rubles for each extra point while my brother was only offering 2 Rubles. In the end, they have settled on 3 Rubles per point. Thus, for example, improving a grade from 3 to 5 on a scale of 2 ("fail")-5 ("excellent"), cost my brother a mere 6 Rubles. ${ }^{9}$ My family members were not unique. As far as we know, everybody was doing this. In fact, through word of mouth communication, people would often share with one another information about the market bribe rate. i.e., how much money a particular public official was taking.

\subsection{Inflating the official prices}

Under-reporting and/or inflating the official prices and pocketing the extra income was the standard as well as the norm amongst the stores' and shops' managers and employees. Much

\footnotetext{
${ }^{7}$ As one of the anonymous referees noted, this kind of payment prior to the receipt of a medical treatment is perhaps different from the gifts medical doctors often receive (usually in kind but sometimes also in monetary terms) after a successful treatment, such as after a successful surgical procedure, as a recognition of a job-well-done. These types of post-medical treatment gifts are quite common in many countries, and it is unclear whether they should be considered a bribe.

${ }^{8}$ The bribe rate for entering the university was in the range of 1,000-1,500 rubles. In addition, often, a payment in kind was also necessary. For example, it was well-known in our community that to purchase an admission to university, it was necessary to give a gift of dvoika (2-piece suit) or preferably troika (3-piece suit) to the university rector's wife. My parents often expressed regret and disappointment for not being able to send my brothers and sisters to the university. The necessary bribe rate was far too high for them and thus not within their reach.

${ }^{9}$ Another brother of mine used chacha-Georgian homemade vodka, to improve his high school diploma grades. Although chacha was sometimes used, money was still the primary means of bribe payments. See section 2.10 below.
} 
of the merchandise these stores sold was produced by Georgian or Russian government manufacturing plants, although some proportion of the merchandise was often imported, typically from Poland, Czechoslovakia, Romania, Bulgaria, and other east European countries. Government officials, who typically were appointed directly by the local or the regional (e.g., district-level) Central Committees of the Soviet Communist Party were in charge of setting the prices of the merchandise. They would set the prices without having any clue about the demand conditions in the market or about the costs of production or importation. In fact, the merchandise was almost always under-priced giving the store employees powerful incentives to inflate the official prices and pocket the profits.

My siblings faced these kinds of situations on a regular basis. For example, a line of work shirts would arrive with the price tags attached to the shirt buttons. In addition to the price information, these tags would also contain information on the manufacturing date and place, washing and ironing instructions, etc. Now, with a price tag of 4 Rubles per shirt, these shirts were grossly under-priced. Therefore, my brothers would order new price tags from a local government printing shop. The new price tags would be identical to the original price tags, with only one difference: instead of 4 Rubles, the tags would indicate a price of 10 Rubles or even 12 Rubles. Then I, along with my younger brother, Joseph, would remove the original tags and replace them with the new tags. We used to inflate this way the official prices dozens of times each year, with the delivery of almost every new shipment of merchandise.

Now, formally the government printing presses were prohibited from printing any nonofficial government document, and certainly from printing fake price tags for illegally selling illegally-manufactured products at inflated prices. Naturally, my brothers had to bribe the printing press managers and especially their director, to secure their full cooperation.

Usually, the size of the bribe that was needed for obtaining a given good or service was not negotiated explicitly. Instead, it seemed that both parties somehow knew what the "right price," i.e., the equilibrium bribe rate was. This knowledge appeared to be a result of the process of accumulation of information over time and learning, through recurring interactions, about the appropriate size of the bribes in different settings and circumstances.

The method of illegally obtaining goods and services in exchange for bribes functioned because everybody that was a part of the group or the circle received his or her share of the profits. The profit sharing mechanism was designed in such a way that all participants had an incentive to play the game according to the rules. It worked precisely because everybody benefited and thus nobody had an incentive to disrupt its smooth functioning. High-rank government officials, the policemen, and the managers at the store-level, all were engaged in 
enriching themselves by dividing the surplus generated. Activities described below and other similar transactions that Georgians were engaged in were thus primarily driven by rent-seeking motives. However, also, and perhaps most importantly, by introducing market incentives, sellers ensured that goods were delivered to the buyers that valued the goods most. Hence, if this was corruption, the type of corruption was of the efficiency enhancing type. ${ }^{10}$

In the particular case of my family, following the unwritten profit-sharing rules, my brothers would share the 200-300 percent "profit" with all "club members." For example, if on a 4 Ruble shirt my brother made 8 Rubles profit, then he would keep 1 Ruble and give 7 Rubles to the store manager. He would pocket one Ruble, and 6 Rubles would go to the director of the bazari. The director and his office employees would keep 2-3 Rubles, and the rest would go to the local police station chief, who would share it further with his fellow policemen as well as with his supervisors in the regional capital. ${ }^{11}$

\subsection{Price adjustment "under the table"}

Often, the decision by how much to inflate the price was left for the last moment. I took an active role in this kind of instantaneous price adjustment, which was done under the table, literally. I was about 7-8 years old at the time. On Sundays, which were the busiest market days, I would go to help my brothers because the market was full with shoppers, as families-many of them from the surrounding villages — came with their children to shop.

My brothers worked outside their stores, behind big table counters. These tables-perhaps about 3.5 meters long and 1.5 meters wide-were enclosed from around and thus were used for storing merchandise. The table counters were covered with merchandise for sale: piles of shirts, pants, socks, etc. Shoes would be scattered between these piles.

My job was to sit inside the table (which was quite easy for me as I was skinny and small) and help my brothers make on-the-spot instantaneous adjustments of shoe prices. I was equipped with a simple metallic device with rotating sharp heads with numeric stamps which I could use to mark any price on the bottom of the shoe.

A customer would come and look at the shoes displayed on the table, which typically would be quite large or really small in size, and which would have no price on it. The customer would ask if we had the shoes in size 43, for example. My brother would at first say: "No, we are out of them." Given the constant shortage of goods and services Georgians were used to this kind

\footnotetext{
${ }^{10}$ For an overview of corruption, and types of corruption, see Aidt (2003).

${ }^{11}$ This is precisely the type of hierarchical rent-seeking described by Hillman and Katz (1987). Marjit, et al. (2000) suggest that existence of such strategic interactions between law enforcement agents on the one hand and the criminals on the other make standard anti-corruption policy prescriptions quite ineffective. See also Klitgaard (1988).
} 
of answer which would therefore not be surprising.

However, most of the customers would also know that at this point, if you truly want the merchandise, you must insist that the seller re-check his inventory, since perhaps there is "one last pair" of size 43 shoes left. Based on how strong and how persistent the customer was in his or her request, my brother would guess the price the customer would be willing to pay, i.e., he would intuitively try to assess the customer's price elasticity. Finally, my brother would bend and "start looking" for the appropriately sized shoes under the table. I already had the shoes ready as I could hear the entire conversation, and my brother would whisper to me the price that he wanted me to mark on the shoes. Within a few seconds, "he would be done searching for the shoes," and luckily, "he would find one last pair" of the requested size. ${ }^{12}$

These and other types of black market activities we were engaged in were possible only because at the official prices there was an excess demand, which gave us the incentive to adjust the prices endogenously to clear the market. The under-the-table instantaneous price adjustment mechanism ensured that the goods that were in excess demand ended up in the hands of those who valued them most. The under-the-table price adjustment mechanism, therefore, was a form of first degree price discrimination.

\subsection{Counterfeit merchandise}

My brothers were also engaged in buying and selling of counterfeit merchandise. The merchandise would be illegally produced by the same government production facilities that produced the "official" merchandise. However, unlike most of the counterfeit merchandise that one may purchase, for example, at the New York's Counterfeit Alley along the Broadway Street in midtown Manhattan, ${ }^{13}$ the quality of our counterfeit merchandise was identical to the quality of the original. For any practical purpose, therefore, the officially manufactured merchandise and the counterfeit merchandise were identical. The only difference was that the production of the counterfeit merchandise would never be reported and thus, as far as government officials were concerned, they "had no knowledge" of its production.

My brothers would purchase the merchandise from the manufacturing plant employees at

\footnotetext{
${ }^{12}$ This story is quite ironic when I consider my current work. I am currently an Economics Professor and my main research area is studying pricing and price-setting within the New Keynesian framework. The specific themes I study include price rigidity and flexibility, size and frequency of price adjustment, cost of price adjustment, menu costs, etc. For example, last few years, I have been conducting research about how much it costs to change the prices at large US supermarket chains or at large US manufacturing firms. See, for example, Levy, et al. (1997, 1998, 2002, 2006, and 2007), Dutta, et al. (1999 and 2002), Levy and Young (2004), and Zbaracki, et al. (2004, 2006). It is ironic when I think what I was doing as a 7-year old boy in Georgia: I was involved in adjusting the prices of various consumer goods and at least once, even incurring a real cost of price adjustment, i.e., a real menu cost: I was arrested by the local police. My crime: illegally inflating the government set prices. My punishment: few hours of jail-time, until my father came to the police station, and paid 150 Rubles along with 2 liters of home-made chacha to the local police chief.

${ }^{13}$ See Confessore (2006) for a detailed description of the New York City's Counterfeit Alley.
} 
a low cost. For example, an exact duplicate of "officially produced" shirts with an official consumer price tag of 3 Rubles could be purchased illegally for 0.50-1.50 Rubles, depending on the quantity purchased, and could be sold for as much as 8-10 Rubles. For the manufacturing plant employees, these were very profitable transactions, as they pocketed all the revenue they obtained from these transactions, but incurred no cost, essentially stealing from the government owned factories. ${ }^{14}$ Obviously, they had to incur the overhead cost of bribing the higher-level management and government officials.

Thus, my brothers' store would receive an official delivery of 50 shirts, for example. If these shirts were popular, then my brothers would purchase and sell as many as 500-1,500 counterfeit copies of the shirts within 2-3 weeks, while the official merchandise would remain on store shelves, most of it unsold.

\subsection{Artificial shortages}

To inflate the official prices more easily, my brothers would often create artificial shortages, as predicted by Shleifer and Vishny $(1992,1993) .{ }^{15}$ In their model, Shleifer and Vishny describe socialist industry consisting of a decision maker who expresses the combined interests of the bureaucrats and the managers. Because such an industry does not keep any of the profits (the government takes it all as if the tax rate is 100 percent), the magnitude of the official profits are of no consequence to the decision maker, and therefore the industry has no interest in charging an official price (which equals the monopoly price) and the monopoly output. Such an industry can make profits only if it creates a shortage of the good it produces and then uses its monopoly power to collect rents in the form of bribes, inflated prices, or side payments from quantity-constrained consumers. Thus, in Shleifer and Vishny’s $(1992,1993)$ model, a government official with monopoly power has incentives to create artificial shortages at the official price, and then collect bribes as a way to clear the market for the government-supplied good. $^{16}$

The method my brothers used was essentially the same, except that the price markup over the official price played the role of bribes. The creation of artificial shortages was typically

\footnotetext{
${ }^{14}$ Shleifer and Vishny (1993) discuss a bribe model with theft in which a corrupt government official hides the sale of a government-provided good or service (e.g., road, import license, passport, etc.) all together and pockets the entire amount. In this type of scenario, Shleifer and Vishny show, the interests of buyers (the consumers who have to bribe a government official) and the sellers (the government officials) are aligned.

${ }^{15}$ Shleifer and Vishny $(1992,1993)$ suggest that many types of restrictive regulations exist for the sole purpose of giving the public officials in charge the power and the opportunity to extract rents (e.g., bribes) from the rationed consumers. For example, when a Moscow taxi driver was asked "... why all the most convenient turns seem to be prohibited on Moscow roads, resulting in huge traffic jams... [his reply was]...so that policemen can collect the most bribes from the violators" (Shleifer and Vishny, 1992, p. 238).

${ }^{16}$ For other (perhaps more traditional) explanations for the persistence of shortages in socialist economies, see Lange (1936), Weitzman (1977), and Kornai (1979). See also Rotemberg (1988), and Abouchar (1977) and the studies included therein.
} 
limited to products that were especially popular, such as imported clothing (e.g., shirts, pants, shoes, etc. from Czechoslovakia, Poland, Hungary, etc.), imported food (e.g., Hungarian and Bulgarian made canned food), and some domestically produced products that were in constant shortage. $^{17}$

Galoshes are a good example of a domestically produced product for which demand was always high and that was constantly in a short supply. Galoshes are overshoes made of rubber and were popular during rainy winter days, especially amongst the peasants and villagers who would often use them as ordinary shoes for working in the field or for walking on the unpaved roads of their villages, because they were unable to afford real shoes.

Supplies of galoshes would arrive to the store 2-3 times a year, and there was always a huge demand for them. People would hurry to stores asking for galoshes but on my brothers' table counters they would find only a single left shoe or only a single right shoe, and when they would ask whether there are galoshes of size 3 or 4 or 5 , etc., they would receive a very typical answer: "No, we are out of them."

If they insisted, however, then my brother would give them a hint: "Well, I do not have any galoshes left, but I can send my little brother to another store, and he might be able to obtain a pair of galoshes of the size you want, but the price will probably be 8-10 Rubles. Also, you will have to give the boy 2-3 Rubles as a gift." They would always agree to the terms of this deal. And of course, I would always manage to obtain for them the right size galoshes in 5 minutes, often with a profit of as much as 400 to 500 percent. The buyers were happy to receive the galoshes, even at the higher price.

\subsection{Human temptations}

Taking advantage of human temptations was a norm in Georgia. For example, when the store received a delivery of cheap plastic wallets, my brother would put just one wallet on the edge of his merchandise table, making it appear as if it had been left there by accident by one of the shoppers. Customers approaching the table counter would notice the wallet, and indeed assume that it was left accidentally by one of the shoppers. My brother would pretend that he has not noticed the wallet. In this type of situation, many customers would pretend that they are looking at the merchandise, quietly pick up the wallet and put it in a purse or in a pocket. At that point my brother would politely inform them: "Sir/Madam, the wallet you just took costs 6 Rubles." Most of the customers would pretend that they intended to buy it, and pay the

\footnotetext{
${ }^{17}$ In Georgia, any product would sell at a premium regardless of its quality, as long as it had anything inscribed on it in any foreign language, i.e., in any language other than Georgian or Russian. Imported goods, therefore, were amongst the most demanded products.
} 
outrageously high price, as otherwise they would be admitting that they were thieves.

\subsection{Fixed versus variable tax}

The profit-sharing arrangement my brothers had with the government authorities was in some sense a form of tax payment arrangement, where my brothers paid tax on a regular basis on the profits earned on every item sold. ${ }^{18}$ This was a variable tax, variable in the sense that the tax payments were linked to the quantity sold: the greater were the quantity sold at the inflated price, the higher the tax payments were.

There was another taxation mechanism that was quite popular in Tskhakaya, which was more like a fixed tax. This tax collection mechanism was implemented by the local police force in the form of periodic raids they would conduct on shops, stores, and other businesses. The police would come and, given their knowledge of the illegal activities that were taking place at these establishments, they would look for a "smoking gun." For example, they would look for items with inflated prices. When these raids occurred, the store manager would quickly organize with the store employees and they would instantly collect money to bribe the visiting police officers. The sums would range between 600-800 Rubles.

There was another mechanism that was often used with the same goal in mind. A policeman would pick a customer whom my brothers would not suspect. The customer would be send to my brother's "ducani" (a store in Georgian) to purchase some product for which the price was inflated. The customer would buy such a product and leave, but later he or she would return with the purchased merchandise, and accompanied by the policeman. On one such occasion, one of my brothers saw his customer was approaching him holding the blouse she has purchased just few minutes before, and she was escorted by a policeman. Instinctively, he ran away, and managed to leave the bazari's grounds despite the police's attempts to quickly seal the market and capture him. It turns out that this particular policeman was an honest policeman, a true communist, a non-corruptible policeman (an oxymoron in Georgia!). My brother, therefore, had to go in hiding for several weeks while the police was searching for him. In parallel, my father was trying to influence this policeman through other (corrupt) police officers. These policemen were paid 1,500 Rubles (which was considered very high price) to convince their fellow police officer to stop chasing my brother.

A raid of similar type took place at an illegal shoe manufacturing facility where one of my brothers was working. The business was located in a residential neighborhood and it was

\footnotetext{
${ }^{18}$ These payments do not constitute an ordinary tax, however, as they would never end at the tax revenue office. Instead, they went to individual policemen and government officials for their private use and benefit, not for the benefit of the general public. Hillman and Schnytzer (1986) refer to these types of payments as "overhead expenditures" or "overhead costs."
} 
producing men's and women's shoes. The shoe materials were pre-cut somewhere else and at this facility the shoes were manually assembled by about dozen workers. This was an illegal operation because in the USSR nobody was allowed to engage in private manufacturing.

In 1966, when my brother was 23 years old, the shop was raided by the city's chief investigative policeman. The policeman came to the shop with a large truck and loaded it with all the materials and merchandise that he found in the shop. However, my brother as well as several other employees managed to escape. He went to a friend's house and from there to the train station and there he took a train to my aunt who lived in Suhumi, the capital of Abkhazia. There he stayed for 3 days, until he learned that it was safe to return home, which meant that bribes were paid to the right people, in this case to the chief investigative policeman. Upon his return, my brother learned that the raid was the chief policeman's personal initiative, a part of his annual "tax collection tour" for the welfare and well being of his family.

Such periodic raids would take place once every 6-12 months, and the payments we were expected to make served as a form of periodic "fixed tax" payments. As always, the payments that my brothers made to the local police force would also reach the functionaries and the bureaucrats of higher government authorities, as their fair share of the "tax proceeds."

There were also annual visits from kantora, the office in charge of monitoring the accounting affairs of government owned businesses. The goal of these visits was to audit the inventory and the accounting balances to ensure that no merchandise or money was missing. In addition to these pre-announced visits, there were also surprise visits from the kantora, which were particularly dangerous because stores could be easily caught with counterfeit merchandise or with merchandise with inflated prices. During such visits, the store would be closed for a day or two, while the kantora officials counted the merchandise and the sales records, and compared them to the information they had in their records.

These types of visits gave the kantora officials opportunities to extract rents from the store management. Although the visits were made only once or twice a year, when they came to town, they would stay for 2-3 weeks and audit perhaps as many as a dozen different stores. The practical aspects of the bribing mechanisms that were typically used in these settings were quite efficient. After all, the entire process was corrupt, and nobody had interest in devoting too much time to haggling about what would be the right and fair bribe rate for each individual store. Such haggling could compromise the discretion of the entire process.

The kantora officials, therefore, did not negotiate individual store bribe rates. Instead, the management of the stores that were raided/visited, would quickly meet, collect a large sum of money, perhaps as much as 5,000-10,000 Rubles in total (about 1,000 Rubles per store), and a 
designated person — typically someone who personally knew one of the kantora officials—would take the money to the official at the hotel as a "gift and a token of appreciation from the local business community."

The process of jointly bribing the kantora's officials was far more efficient than an alternative mechanism where each individual store manager makes individual store bribe payments. That is because the bribe payments were all collected and channeled together to the kantora officials similar to the way that banks channel individual savers' funds to investors, substantially reducing the transaction cost. After such payments were made, any discrepancies and problems that were found during the audit of the stores were suppressed and never included in the final report. If it was determined that there was money missing, then obviously the store management had to resolve it. However, other types of problems such as over-priced merchandise, counterfeit merchandise, etc. would be completely overlooked and never reported.

\subsection{The power of "chacha"}

One of the most remarkable things about Russia, and perhaps about the rest of the USSR, was the unusually high purchasing power of homemade vodka, or chacha in Georgian. My father, like other Georgians, used to make chacha from the remains of grapes, after making wine from them. The quality of chacha was determined by pouring it on a plate and throwing in a burning match. If it caught fire, then it was of a high quality. In other words, it was a... pure alcohol, no different than... after-shave. ${ }^{19}$

Now, with such home made vodka, one could obtain in Russia everything and anything, from domestically grown produce to imported consumer goods to machine guns, etc. ${ }^{20} \mathrm{We}$ discovered that with home made vodka we could accomplish a lot even in Georgia. One of my brothers, for example, paid two bottles of chacha to his school teacher to have his high school diploma grades improved. In 1970, my father used 4 liters of homemade chacha along with 400 Rubles to have our home connected to the town's electric grid, which by the way, was supposed to be done for free.

\footnotetext{
${ }^{19}$ According to a recent report in the Tel-Aviv edition of the International Herald Tribute, Iranians, like the Georgians, have been producing, bottling and selling home-made vodka and wine for centuries. It turns out that despite the increased attempts by the Iranian authorities to enforce the existing laws that prohibit the consumption of alcohol, Iranians apparently are consuming bootleg home-made vodka and wine in increasing quantities. According to the article, some young Iranian entrepreneurs are even engaged in the highly risky business of delivering the outlawed drinks on scooters to their clients' homes, which points at the universality of the laws that govern humans' response to incentives. See Fathi (2006).

${ }^{20}$ A common perception in Georgia was that chacha's purchasing power in Russia was far greater than in Georgia. We discovered in 1971 that this was indeed the case when we were leaving Soviet Union. On the way from Georgia to Tel-Aviv, we passed through Moscow and later through Brest, and we discovered that we could accomplish so much more in these two cities by using chacha, substantially more than in Georgia. For example, various types of bribes that we had to make in "chacha units" in Russia were much lower than in Georgia for similar kinds of goods or services. The main reason for this discrepancy in the vodka's purchasing power was the Russians' love for vodka. They valued it far more than Georgians. For Georgians, wine always ranked first. The purchasing power of vodka, therefore, was far lower in Georgia than in Russia.
} 
To have one of my brothers accepted to an evening school, all my father had to do was to pay a late night visit to the school director's home and bring along 2 liters of home made chacha. We sometimes went to a doctor's office with a bottle of home made wine, although wine was not as popular as chacha as a means for making bribe payments, and thus its purchasing power was far lower. However, my father's homemade wine was considered pure (he never used any additives) and of a superb quality, and the entire town knew about it. ${ }^{21}$ My father's homemade wine, therefore, was capable of helping us in many of our economic transactions. In particular, about 5 liters of it, along with a payment of 1,500 Rubles to the Military Commissariat's officers, were sufficient for one of my brothers to obtain an exemption from serving in the Soviet military during a peace-time period. During war time, no amount of money, vodka, or wine would help: everybody would be mobilized for the Soviet military.

\subsection{Barter exchange}

Transactions involving barter exchanges were not limited to chacha and homemade wine. Although chacha and wine were sometimes used in bribing as a form of commodity money, they typically served more as a supplementary side-gift, while monetary payments comprised the main component of a bribe. ${ }^{22}$ Barter, however, was common in Soviet Georgia. Along with other people in our town, we routinely exchanged goods and services. These exchanges were illegal, as they took place outside the official markets, typically involving goods and services that were produced outside the official production plans and facilities. Also, the transaction prices differed from the official prices, as they varied from transaction to transaction.

For example, my father and one of my brothers (as well as one of my uncles) worked as glazers, which meant that they would install glass (or replace if broken) in windows, picture frames, etc. Sometimes people came to our house with a picture frame or with a window frame and my father or my brother would cut glass and install it in these frames. But, most often, my father and brother would go around in the streets of our town as well as the surrounding villages and towns, carrying several quite heavy and large pieces of glass, often as large a $1.5 \mathrm{~m}$ by $0.80 \mathrm{~m}$ each, on their shoulders, and offering their services to people. In exchange for their services, my father and brother would be often offered payment in kind. These would include homemade

\footnotetext{
${ }^{21}$ We used to make the wine at home, which was allowed because it was a form of private activity, no different from homecooking. The men and the boys of the house would wash their feet, while the women would wash the grapes. And then, the men and the boys would jump into giant pots and trample the grapes. The resulting grape juice would be kept in jars for 4-5 years, while passing it through a periodic filtering process using simple cheesecloth. After 5 years, the wine would be ready. During a visit to Tel-Aviv's Museum Haaretz, the tour guide explained how Byzantines used to make wine. The guide was amused to hear that we used to make wine in Georgia "the Byzantine way" as recently as 35 years ago.

${ }^{22}$ Thus, although chacha did serve in Georgia at times as a commodity money, it did not attain the same degree of universal acceptance as cigarettes did at the P.O.W camp according to Radford's (1945) account, or as red Mexican dry beans did in barter exchange market simulations according to Levy and Bergen's (1993) and Fried and Levy's (1995) account.
} 
cheese, various types of fruits and vegetables, dry beans, dry fish, etc. Other barter transactions would include dental services, carpentry projects, used clothing, medicine, etc. ${ }^{23}$

\subsection{Cost of praying}

Religious practice was officially outlawed in the former Soviet Union. Instead, in Georgia as in much of the former USSR, Lenin, Marx, and Engels were the gods and their teachings (e.g., the Communist Manifesto) were the bible. Nevertheless, the city Jews somehow found a way to have the authorities allow the local Jewish community to build a synagogue. It was quite strange, however: the signs at the entrance to the synagogue indicated that it was prohibited to pray there. It was supposed to be a place for social gathering only.

We, however, practiced our religion and were able to hold regular daily prayer services at the synagogue because the local congregation collected money on a regular basis and arranged a generous bribe payments to the local city and police authorities. Thanks to small extra payments, they even permitted the families to bring along their kids to the Sabbath services.

Peoples of other religions, including Christians and Muslims, faced similar restrictions, although it seemed that Christianity was sometimes more tolerated than the other religions. That is particularly true for the Georgian Orthodox church, which at times was allowed to function almost freely. For example, during World War II, it was allowed greater autonomy in running its affairs in return for the church's call to its members to support the war effort.

In general, however, the Soviet rulers actively encouraged atheism, and brought severe purges upon the Georgian church hierarchy and frequent repression of Orthodox worship. In many parts of Soviet Union, including in Georgia, churches, mosques, and synagogues were destroyed or converted into secular buildings. Many churches that were particularly old (e.g., from the $11^{\text {th }}-16^{\text {th }}$ century), were converted into museums. ${ }^{24}$ Consequently, people often practiced their religion in their own private homes in small groups. ${ }^{25}$

\footnotetext{
${ }^{23}$ According to Demetriou (2002), during the recent transition period, grenades, machine guns, and other types of small arms served as a medium of exchange in Georgia. Demetriou (2002, p. 16) reports that "According to several sources, weapons during the conflict and the early post-conflict period in effect served as a form of currency in a barter-dominated economy. Hyperinflation in Russia during that time meant that Russian rubles (Georgia's currency until 1995) were an unstable medium of exchange. Because they [the weapons] were available in large (and constant) quantities and not sensitive to fluctuations in the currency market, weapons thus substituted for the ruble to a certain degree. One teacher of English in Tbilisi [the capital of Georgia], for instance, recollected having been paid in grenades for lessons he had provided to an elderly woman. Similarly, the Mkhedrioni [a Georgian paramilitary group and political organisation outlawed since 1995 but subsequently reconstituted as the Union of Patriots political party] were able to acquire significant influence in criminal and political clientalistic networks through the distribution of weapons as "gifts" to powerful underground figures, economic directors, and political patrons."

${ }^{24}$ See, for example, Kaiser (1997), and "Unit 9: Religious History - Georgia" at http://www.globalsecurity.org/military/library/report/1999/nis/index.html.

${ }^{25}$ For example, in the late 1960 s our city synagogue was burned by arsonists. When the construction of the new synagogue building was completed, it was taken by the authorities and converted into a soft-drink manufacturing plant. Having no place of worship, the local Jews would often gather in our house to hold religious services. According to some accounts, Islam survived in the USSR thanks to the ability of the Muslims to practice their religion at home. (Source: http://www.georgefox.edu/academics/undergrad/departments/soc-swk/ree/MALIK2.html).
} 


\subsection{Cost of exit visa}

In 1971 my family left the Republic of Georgia for good and immigrated to Israel. The process of obtaining the exit visa was full of hurdles and obstacles that without side-payments would be impossible to overcome. It began with an "invitation" from the Government of Israel. The invitation was necessary for requesting an emigration permit. ${ }^{26}$ The invitation was arranged through other emigrants who had left Georgia before us.

When the invitation arrived at the local post office, the post office director saw a profit opportunity. This was the standard practice: every time a letter came from overseas, usually from a family in Israel, the postman would come to our house, and tell my parents quite directly and explicitly: "I have a letter for you from Israel. How much are you willing to pay for it?" Typically, one or two shots of chacha along with 50.00 Rubles would suffice.

The value of an invitation from the government of Israel, however, was much higher than a single family letter. The post office director recognized this and took advantage of this profit opportunity, given his monopoly power over releasing the letter. In the end, it cost the family close to 600.00 Rubles to obtain the document from the post office. ${ }^{27}$ This, however, was only the beginning. The employees of the local office that issued birth certificates were unable to locate our birth certificates. However, a bribe payment of 150.00 Rubles per certificate helped them locate the lost certificates.

Then there was a passport office in Tbilisi. There we were sure that we would be expected to make a substantial contribution towards the happiness and welfare of the passport office head and his family. It turns out, however, that the person in charge was originally from Tskhakaya, a former star in the town's soccer team. He recognized my father and my brothers and told them that he is not going to take any money from "his old comrades." 28 That was a huge saving for the family.

The last encounter we had with Soviet authorities was in the city of Brest, on the border between Belarus and Poland. This was our point of departure from Soviet Union to Israel. The Soviets did not allow emigrants to take with them many of their possessions. The border police in Brest, however, were more than willing to allow us to stuff the boxes we wanted to ship with

\footnotetext{
${ }^{26}$ According to a recent report of Human Rights Watch (www.hrw.org), the former republics of the USSR have almost completely eliminated the need to obtain an invitation from a foreign government to travel abroad or to emigrate.

${ }^{27}$ Because the post office director was a monopolist in this case, the "price" we ended up paying for the invitation letter primarily reflected my family's ability to pay.

${ }^{28}$ This is similar to the "identifiable victim effect" (Loewenstein, et al., 2007; Small and Loewenstein, 2003), which predicts that a greater sympathy will be shown towards identifiable than statistical victim. In the case of Georgia, it appears that it was "ok" to cheat or to steal from someone who you did not know in person. Social norms, however, prohibited acting dishonestly with people whom you knew in person.
} 
anything we wanted, all in exchange for just one bottle of chacha per policeman.

\subsection{Labor markets}

In Georgia a person could only be employed by the government. No private enterprise was allowed. Even if one had a job that in the west would be described as self-employment, in Georgia he or she had to be registered at a government office, called arteli, which was considered his official employer.

For example, my father and one of my brothers were registered with the local arteli as glazers. In theory this meant that arteli's officials could tell them what to do. For example, they could keep them busy by sending them to various government construction projects where glazers were needed. In addition, because arteli was their official employer, they were supposed to receive their monthly salary from arteli. Officially, they were not supposed to sell their services to private individuals.

All these rules were only in theory, however. That is because, like most of the selfemployed people, my dad had also bribed (quite generously) the arteli's key officials, and therefore he was rarely called to government run projects. In the rare occasions that he was called, he was rewarded by receiving fairly large quantities of uncut glass for his private business use. For example, periodically he would be called to a government construction project to install window glasses. These sites usually would have large supplies of glass, and the construction supervisors at these sites would often offer him to take some of the uncut glass for private use, because they would almost always receive deliveries of construction materials in excess quantities.

But, perhaps more importantly, thanks to the bribe payments, my father was permitted to sell his glazing services to private individuals quite openly. Moreover, he never reported his income to the arteli's officials, despite the strict regulations that required full reporting of all incomes from all private transactions. In fact, each "self-employed" employee of arteli was required by the Soviet labor and employment laws to hand in all the income he or she has earned from private transactions. That would count as his or her contribution to the benefit of the proletariat. In return, the employed would receive the government prescribed 30-60 Rubles, the monthly salary. Thus, arteli was a guild-like association that extracted a tax for membership.

Now, as far as we know, nobody ever handed in their privately earned income to arteli. The entire thing was a big joke. Arteli's apparatus was full of rent-seeking bureaucrats whose chief goal was to reach as many independent, self-employed individuals as possible to extract rents. My father, for example, would go to arteli's offices towards the end of each month and 
would report and hand in his 30-Ruble privately earned income for the previous month. Needless to say that nobody would ever question the accuracy of his reported income, which always was ridiculously low. In exchange, my father would receive his monthly 30 Ruble salary from arteli. Of course, the monthly salary payment from arteli was quite minor in comparison to the actual income he regularly earned from his private glazing works. By the mid 1960s, my father got tired of these games, and with an additional lump-sum bribe payment, he obtained a permanent exemption from ever reporting to arteli. Later on, he obtained similar exemptions for my brother and my uncle.

\section{Was corruption in Georgia efficient?}

According to one point of view in the literature, corruption can be efficient under some circumstances. See, for example, Leff (1964), Huntington (1968), Lui (1985), Beck and Maher (1986), Lien (1986), Aidt, et al (2005). According to this view, in economies where the economic dominance of government-run monopolies along with bureaucratic rigidities leads to inefficient outcomes (e.g., to constant shortages), corruption can serve as a means for achieving a higher degree of economic efficiency by "greasing the wheels" of government and overcoming cumbersome government bureaucratic regulations (red tape) by giving the bureaucrats the incentive to make their work more efficient despite the institutional and bureaucratic rigidities under which they operate (Blackburn, et al. 2006). ${ }^{29}$

In Georgia's centrally planned command economy, the government officials and bureaucrats were the ones that made the decisions of what will be produced, how much will be produced, and for whom will be produced. Thus, in Georgia, one of the main causes of corruption was state control over the distribution of the basic resources. The control manifested itself in the cumbersome and inefficient state management system, which made it impossible for individuals to obtain any service from the government without paying a visit to dozens of government officials in various offices. The state control over all economic decisions also resulted in constant shortages of goods and services. In the absence of free markets with flexible price and wage system, Georgian decision makers had to find ways around the restrictions imposed by the centrally planned economic structure, and its inefficient price system. In Georgia, therefore, the problems created by central planning were resolved, at least in part, by developing a black market, a parallel market where many goods and services were traded outside the official markets.

Clearly, the corrupt black market activities in Georgia's economy had direct distributional

\footnotetext{
${ }^{29}$ Bardhan (1997) questions these types of arguments on conceptual grounds.
} 
effects as people were stealing from one another and from the state. But there were also indirect distributional effects through externalities. For example, the money that individual profit seekers routinely pocketed, could in principle be used for a common good if it were to reach the country's treasury. However, it is more than likely that the corrupt economic activities of Georgian people were socially costly as well because significant amount of resources were devoted to the management of illegal black market activities and to the efforts to cover them up.

Nevertheless, while more data are needed to give a clear answer to the question this section asks, it seems clear that the corruption allowed the Georgian economy to produce far more output than would be produced otherwise. As in the case of Food Store Five of Hillman and Schnytzer (1986), the corrupt rent-seeking activities in Georgia enabled the economy to sustain production. Therefore, to the extent that illegal black market activities allowed greater production and consumption of goods and services, and assuming that the centralized market structure was exogenously imposed on Georgians (Aidt, 2003), the corruption in Georgia likely was efficiencyenhancing.

\section{Ethical and moral aspects of the corruption in Georgia}

A reader might wonder why we behaved as we did. The answer to this hard question is actually quite simple and twofold. First, we had no choice. There was no other way a family could live and survive in Georgia without being engaged in these types of illegal activities. ${ }^{30}$

Second, and perhaps not less important, it was the norm. Everybody was doing it, and that provided ethical and moral justification for our actions without feeling too much guilt or embarrassment about it. The society saw this as a necessary evil, and usually blamed the regime for it. Therefore from the point of view of ethics, bribing, mark-up pricing, side-payments in cash and in kind, and other similar kind of black market activities were not considered immoral. To the contrary, it was considered perfectly normal, and a part of the everyday life in the former

\footnotetext{
${ }^{30}$ A reader might have the impression that, given the sophisticated schemes, cheatings, rip offs, etc., in which some of my family members were engaged, our family must have been quite wealthy. The truth, however, is quite opposite. Most of the income the family earned was spent on food and other necessities and not much was left for anything else. That is primarily because we were a family with ten children. Consider the following: unlike our neighbors, we did not have running water (which means that we did not have showers, flushing toilets, etc.). Also unlike our neighbors, we did not have a refrigerator, a washing machine, a gas burner, an electric oven, a telephone, a TV (we often went to our neighbors to watch a soccer game on TV), nor any other standard home appliance. In fact, we did not even have electricity until 1970, about a year before we left the Soviet Union. Until then, we were completely dependent on candle-light and kerosene-lamps. We rarely purchased new clothes. As far back as I remember, I always wore my older brothers' clothes. They also wore used clothes, which came from various second hand sources (e.g., wealthy families). We always purchased black bread because it was cheaper. We would eat chicken once a week, and beef perhaps once every few weeks. Because robber boots were too expensive, in cold Georgian winters we often wore galoshes, which were very inefficient when snow accumulated. For many years, we played using a home-made soccer ball because a real soccer ball was too expensive. Soccer shoes, which most of my friends had, were out of question! None of my siblings attended an institute of higher education in Georgia because my parents could not afford it: the necessary bribe rate was too high. The family had to save all year long for my mother's annual summer trip to various mineral water sources because mineral water was considered good for diabetics. In short, our living standard was quite low, to say the least.
} 
Soviet Union. Even worse types of crimes, such as stealing, cheating, ripping offs, etc., which would be considered ethically less defensible to most people under normal circumstances, were considered socially acceptable in Georgia as long as the thief had no personal knowledge of the person he was stealing from. Unwritten social rules prohibited stealing from people you knew in person, such as friends, neighbors, co-workers, etc. The current President of Georgia, Mikhail Saakashvili has said: "Georgia was a very corrupt country. Sometimes people don't believe that it was corrupt because it was part of culture" (my emphasis). ${ }^{31}$

Georgia is still considered one of the most corrupt countries in the world. The existing evidence, however, suggests that corruption is not limited to underdeveloped and developing countries. There is ample evidence about existence of corruption in developed countries as well (Elliott, 1997; Glynn, et al. 1997; Rose-Ackerman 1997; Rodrik and Rauch, 1997). ${ }^{32}$ For example, some of the Western European countries, such as Italy and Greece, as well as some other highly developed countries such as Japan and Korea, are well-known for the political and economic corruption. There is evidence about corruption in the US as well. For example, Glaeser and Saks (2006) use data on federal corruption convictions to study the causes and consequences of corruption in the US. According to their account, between 1990 and 2002, US federal prosecutors convicted more than 10,000 government officials of acts of corruption such as conflict of interest, fraud, campaign-finance violations, and obstruction of justice. Germany, as another example, also seems to have its share of corruption, as do France, Italy, and Japan (Pascha, 1999). ${ }^{33}$

Most of these countries have decentralized and free market based economic systems to a varying degree. Nevertheless, the existence of corruption in these countries suggests that corruption has many possible sources, beyond a rigid centralized price system of the type that existed in Georgia. Indeed, scholars have noted numerous economic as well as non-economic causes for corruption (see Elliott, 1997 and the essays included therein). In some areas of commerce, corruption seems to be an ethically as well as socially acceptable norm, and this phenomenon is not limited to poor or developing countries. An example is the piracy of software, music and movies via sales of illegal copies, internet downloads, or just computer-to-computer

\footnotetext{
${ }^{31}$ Source: "Georgian President Visits Atlanta," Georgian President Mikhail Saakashvili's interview with Elina Fuhrman on the National Public Radio, Wednesday, August 11, 2004, NPR, available at the web site of Georgia's Embassy in the US, http://www.georgiaemb.org/DisplayMedia.asp?id=355. Marjit, et al. (2000) make a similar suggestion: "It [corruption] is so pervasive that citizens in the developing part of the world have accepted it as a social rule" (p. 76). See also Ludwig and Kling (2006).

${ }^{32}$ We should point out, however, that the empirical evidence still suggests that the more developed countries tend to have less corruption (Treisman, 2000).

${ }^{33}$ According to Glynn, et al. (1997, pp. 22-23), “...corruption in Germany has by no means approached the ministers-for-sale levels seen in France and especially Italy... [however] a spate of scandals has dealt powerful blows to the German national selfimage, and corruption has emerged as an explosive issue for German politicians." Also, according to the 1995 European Business Report, the German construction industry allegedly paid 10 billion marks to corrupt officials each year.
} 
exchanges. Another part of that market, it turns out, also trades (sometimes quite openly) in illegal decoders and smart cards used to descramble encrypted satellite signals to access TV channels and other information sources. The remarkable aspect of these piracies and illegal activities is that they are very common and widespread in some of the most advanced countries, including such European countries as Norway and Sweden, countries that are presumably regarded as highly ethical. ${ }^{34}$ The persistence of such illegal activities in advanced countries suggests that corruption has strong elements of social norms, as suggested by Fisman and Miguel (2006).

\section{Generalizability of the evidence}

The cases and the events I have described are consistent with similar, although not as detailed, accounts offered by Simes (1975), Simis (1977, 1982), Grossman (1977), Bergson (1984), and Hillman and Schnytzer (1986). For example, according to Simis' (1982, pp. 155156) account, in order to have his business survive in Georgia, one Food Store Five's manager had to "...take money from the sales clerks, to sell goods at inflated prices, to cheat the customers, and, of course, to bribe the top people in the municipal administration, and all the store's suppliers" [my emphasis]. This description summarizes quite well the types of activities many Georgians were engaged in, which suggests that the events I described above were not limited to my immediate family members or to the time period this paper covers. Indeed, the ways my family used to deal with the restrictions and inefficiencies of Georgian economy were not unique in the sense that all of our neighbors and friends had to adopt similar methods and techniques to survive. The anecdotal evidence I offer, therefore, is quite typical and generalizes to behavior in Georgia.

Although it is well known that the other republics of the former Soviet Union were also corrupt, it is also well-known that Georgia was the most corrupt. It is unclear, therefore, whether the various types of unethical behavior I have described here, also existed in other places. I suspect that they did, but not to the same extent as in Georgia. Åslund (1997) emphasizes an important difference between the Central/Eastern European countries and the former Soviet republics. Åslund argues that there was much less rent-seeking in the Central and Eastern

\footnotetext{
${ }^{34}$ According to the February 13, 2006 report of the International Intellectual Property Alliance, "Significant Internet source piracy infrastructure and group membership have flourished in Sweden due to this country's notoriety as a piracy safe haven. Pirates have even established a Political Party — the "Piratpartiet" — which plans to participate in the general election later this year on a platform demanding the removal of national copyright laws. Topsites, highly specialized types of pirate servers with massive storage and extremely high bandwidth, are used by Encoding/Release Groups for the first release of pirated content on the Internet. This source content is then passed down ... to Internet Relay Chat (IRC), Newsgroups and peer-to-peer (P2P) networks...there are approximately 200 [Topsites] in the world and... 40\% of the European sites of this type, are hosted in Sweden. The country has the largest number of direct connect hubs (P2P facilitators) and the most Direct Connect users in the world. Finally, Sweden is home to Rizon, one of the largest IRC networks in the world."
} 
European countries, which he ascribes to fewer economic distortions, more economic openness, better legal norms, better-functioning state institutions, and to stronger civil societies these countries had in comparison to the former Soviet Union, where the old elite had been and remained amazingly free of social controls. ${ }^{35}$

An interesting issue (raised by one of the referees) concerns the difficulty of explaining the prevalence of corruption in Georgia circa 2006 in light of the fact that the economic system that gave rise to it has gone. Some of the corruption in Georgia may be transitional. As Huntington (1968), Kornai (1990) and Shleifer and Vishny (1993) observe, democratization of a country's political and economic systems is often accompanied by increased rather than decreased corruption, or in the terminology of Hillman and Ursprung (2000), by increased rent seeking. ${ }^{36}$

The corruption in Georgia seems to have a strong component of historical and social norm which likely is contributing to the persistence of corruption in today's Georgia despite the recent political and economic reforms. The existence of these norms makes it unlikely that the corruption will disappear any time soon despite the current Georgian government's extraordinary efforts. Existence of these types of social norms, customs and rules, therefore, suggest that Georgia and other countries like it could be stuck in a "corruption trap" for awhile.

\section{Anecdotal evidence - potential benefits}

Although corruption appears to be a widespread phenomenon across the globe, direct data on corruption and its prevalence is scarce because of its illegal nature. The absence of data can limit the attention that corruption-related problems receive in policy discussions.

There seems to be plenty of anecdotal evidence about prevalence of corruption that is not or is rarely published in academic studies, perhaps because the economics discipline until recently tended to be in general unreceptive to anecdotal evidence. There are several possible reasons for this. One reason is that, because of its informal nature, anecdotal evidence is difficult to verify. Second, various forms of potential cognitive biases may affect the recollection or the presentation of such evidence. Also, some might consider anecdotal evidence statistically less reliable than other types of evidence because they do not necessarily represent a typical or an

\footnotetext{
${ }^{35}$ Comments from one of the anonymous referees are consistent with this argument. For example, according to the referee (who apparently lived in one of the East European countries during the 1960-1980s), he/she has "... never seen or heard of any price manipulations such as described [in this paper] by the author with the exception of..." Similarly, the referee continues, “... regarding education, I have never heard or witnessed bribery at the elementary or high school level." It turns out, however, that the referee's home country had a relatively free market with little central planning. This could explain the lack of significant corruption in his/her country, as suggested by Åslund (1997). See also Treisman (2000).

${ }^{36}$ Consistent with these observations is the existing empirical evidence which shows that there is no simple correlation between the levels of democracy and corruption. See, for example, Johnston (1997) and the studies cited therein. See also Glynn, et al. (1997), Aidt and Dutta (2004), and Blackburn, et al. (2006).
} 
average behavior.

As mentioned above, however, increasing number of scholars recognizes the value of anecdotal evidence as a useful supplement to more standard and more commonly accepted statistical evidence, especially in situations where data from regular sources are non-existent. Anecdotal evidence offers information on the extent and frequency of corruption, which sheds light on the nature, causes, as well as consequences of corruption. Therefore, anecdotal evidence, if collected in substantial quantities and across many countries, can be fruitfully used as an input in improving the construction of various corruption indexes, such as the ICRGI, IMDI, and CPI, which already use anecdotal evidence obtained from surveys.

\section{Conclusion}

The former Soviet Union was a centrally planned economy, where government officials in principle made all the decisions for the people, decisions that in market economies are usually left to private individuals and to free markets that rely on a flexible wage and price system. The examples documented in this essay are based on first-hand accounts and suggest that individuals that operate in inefficient constrained environments have incentives to find ways around the constraints, even if that means taking risks by engaging in illegal activities.

Although the period described in this study covers the years 1960-1971, the market structure and the social organization of the illegal economic activities that I have described existed in Georgia under the communist regime well before 1960s, as well as after 1971. While there were attempts to confront corruption, it turns out that many of these attempts were not real: they were what Hillman and Schnytzer (1986, p. 96) call “... purges... [that reflect] successful rent-seeking endeavor. The illegal activities underlying the rents continued with a newly specified property rights designation." 37

Thus, the system, the police, and the government officials, all were corrupt. My family responded to market incentives and behaved in accord with norms. Indeed, my intention has been to describe the norms.

Corruption and the black market mechanisms emerged endogenously in Georgia because the Soviets did not allow free markets. In parallel to the official market, well-functioning black markets developed. Many Georgians believed that Georgia itself was one big black market.

\footnotetext{
${ }^{37}$ According to Human Rights Watch, the situation in Georgia in terms of corruption continued worsening until the "Rose Revolution," when Shevardnadze was forced to resign on charges of corruption. However, the corruption in Georgia was so bad that I personally find it hard to see how it could get any worse. After all, anything corruptible was already corrupted. I, therefore, suspect that there was no significant increase in the corruption. Instead, I believe that with the continuous political reforms, more and more of the existing corruption was exposed and brought to public attention, which likely contributed substantially to the downfall of Shevardnadze.
} 
Indeed, Georgian economy had prospered and Georgians were enjoying a relatively high standard of living in comparison to the rest of the Soviet Union, at least in part, thanks to the "free market institutions" that Georgians were able to establish and promote. For example, according to Tavartkiladze's (1998) report produced for Helio International, the Georgian's standard of living by the end of the Soviet era was one of the highest in the entire USSR. Similar assessments are reported by Åslund (1997) and Åslund, et al. (1996).

Georgia was corrupt at all levels of government, beginning with the highest ranking communist party members in Tbilisi, all the way to the low-level office workers in small towns and cities. To achieve anything, bribing and making side-payments to the right government bureaucrats and functionaries, and quite often even to the local police officers, was necessary. Various types of profit sharing mechanisms that the Georgians have developed were designed in such a way that all participants had incentives to follow the unwritten rules. The system worked precisely because everybody benefited from it and nobody had incentive to disrupt its smooth functioning. Transactions were primarily driven by rent-seeking motives, which in turn gave the Georgians incentives to engage in productive activities despite the Georgia's centralized market's totalitarian constraints and limitations.

These conclusions suggest that the true output of Georgia was significantly higher than the officially recorded state-produced output, which suggests that the true post-Soviet period depression in the output that occurred during the post-transition years from 1991 to 1995 was greater than originally thought. ${ }^{38}$ For example, according to Tavartkiladze (1998), GDP per capita in 1995 amounted to 483 Georgian Lari, equivalent of about $\$ 383$, which is about 18 percent of the per capita output in 1990. Åslund, et al. (1996) and Åslund (1997) report a slightly lower estimate, about 14 percent. The anecdotal evidence offered in this paper suggests that the true decline in the output of Georgia was perhaps even sharper.

Corruption continued to exist in Georgia even after the collapse of the Soviet Union. The Georgian government did not begin taking serious anti-corruption measures until President Saakashvili rose to power in 2003. ${ }^{39}$ According to Transparency International's CPI, as lately as in 2003, Georgia still was one of the most corrupt nations in the world — on a par with Tajikistan and Azerbaijan and outranked only by countries such as Myanmar, Haiti, and Paraguay.

Was corruption in Georgia efficient? Georgians clearly spent a substantial amount of resources on the management and the cover up of corrupt economic activities. Nevertheless, the

\footnotetext{
${ }^{38}$ This assumes that the output during the mid 1990s was measured with greater precisions than before. The accuracy of this assumption, however, is hard to assess.

${ }^{39}$ For example, according to the 1998 estimates of the Georgian State Department of Statistics, the informal (or "black market") economy contributes over one third of the country's GDP (Tavartkiladze, 1998).
} 
corruption allowed the Georgian economy to produce far more output than would have been produced otherwise and avoid the impoverishment that communism in general brought. The corruption in Georgia, therefore, likely was efficiency-enhancing. According to Huntington (1968, p. 386), "In terms of economic growth, the only thing worse than a society with a rigid, over-centralized, dishonest bureaucracy is one with a rigid over-centralized, honest bureaucracy." This may have been the case with Georgia. 


\section{Acknowledgements}

I am grateful to three anonymous referees for thoughtful comments and suggestions and to Arye Hillman for comments and guidance. I thank also Toke Aidt, Bob Barsky and Mark Bergen for useful conversations, Adi Schnytzer for comments, and Steve Ziliak for his help in locating some relevant references and sources. Finally, I thank the members of my extended family and especially my brothers Abraham, Isaac, Pinkhas, Samuel, and Joseph for helping me gather many of the details of the events reported here, and Avihai and Sarit Levy for comments. All errors are mine. 


\section{References}

Abed, G. T., Gupta, S., 2002. Governance, Corruption, and Economic Performance. International Monetary Fund, Washington, DC.

Abouchar, A. (Ed.), 1977. The Socialist Price Mechanism. Duke University Press, Durham, NC.

Aidt, T.S., 2003. Economic analysis of corruption: A survey. The Economic Journal 113, F632F652.

Aidt, T.S., Dutta, J. 2004. Policy compromises: corruption and regulation in a democracy. Cambridge Working Papers in Economics, No. 0404.

Aidt, T.S., Dutta, J., Sena, V., 2005. Growth, governance and corruption in the presence of threshold effects: theory and evidence. Cambridge Working Papers in Economics, No. 0540 .

Åslund, A., 1997. Possible future directions for economies in transition. In: Nelson, J.M., Tilly, C., Walker, L. (Eds.), Transforming Post-Communist Political Economies, National Academy Press, Washington, DC, pp. 453-470.

Åslund, A., Boone, P., Johnson, S., 1996. How to stabilize: lessons from post-communist countries. Brookings Papers on Economic Activity 26, 217-313.

Bardhan, P., 1997. Corruption and development: a review of issues. Journal of Economic Literature 35, 1320-1346.

Beck, P., Maher, M., 1986. A comparison of bribery and bidding in thin markets. Economics Letters 20, 1-5.

Bergson, A., 1984. Income inequality under Soviet socialism. Journal of Economic Literature 22, 1052-1099.

Blackburn, K., Bose, N., Haque, M.E., 2006. The incidence and persistence of corruption in economic development. Journal of Economic Dynamics and Control 30, 2447-2467.

Confessore, N., 2006. No-name, brand-name or phony: it's all here. New York Times, October 9, Monday, Late Edition - Final, Section B, Page 1, Column 1.

Demetriou, S., 2002. Politics from the barrel of a gun: Small arms proliferation and conflict in the Republic of Georgia, 1989-2001. Occasional Paper No. 6, Small Arms Survey, Graduate Institute of International Studies, Geneva, Switzerland.

Durlauf, S.N., 2001. Manifesto for a growth econometrics. Journal of Econometrics 100, 65-69.

Dutta, S., Bergen, M., Levy, D., Venable, R., 1999. Menu costs, posted prices, and multiproduct retailers. Journal of Money, Credit, and Banking 31, 683-703.

Dutta, S., Levy, D., Bergen, M., 2002. Price flexibility in channels of distribution: Evidence from scanner data. Journal of Economic Dynamics and Control 26, 1845-1900.

Easterly, W., 2001. The Elusive Quest for Growth: Economists' Adventures and Misadventures in the Tropics. The MIT Press, Cambridge, MA.

Elliott, K.A., 1997. Introduction. In: Elliott, K.A. (Ed.), Corruption and the Global Economy, Institute for International Economics, Washington, DC, pp. 1-5.

Fathi, N., 2006. It's hard to kick a 7,000-year-old habit. International Herald Tribune, Tel-Aviv Edition, April 4, 2006, p. 1.

Fisman, R., Miguel, E., 2006. Cultures of corruption: evidence from diplomatic parking tickets. National Bureau of Economic Research, Working Paper No. 12312.

Foellmi, R., Oechslin, M., 2006. Who gains from non-collusive corruption? Journal of Development Economics 82, 95-119.

Fried, H., Levy, D., 1995. Beans as a medium of exchange. In: Delemeester, G., Neral, J. (Eds.), Classroom Experiments: A User's Guide, a volume accompanying John Taylor's Principles of Economics, Houghton Mifflin, New York, NY, pp. 120-124.

Glynn, P., Kobrin, S.J., Naím, M., 1997. The globalization of corruption. In: Elliott, K.A. (Ed.), Corruption and the Global Economy, Institute for International Economics, Washington, 
DC, pp. 7-27.

Grossman, G., 1977. The second economy of the USSR. Problems of Communism 26, 25-40.

Gupta, S., de Mello, L., Sharan, R., 2001. Corruption and military spending. European Journal of Political Economics 17, 749-777.

Hertzfeld, T., Weiss, C., 2003. Corruption and legal (in)effectiveness: An empirical investigation. European Journal of Political Economics 19, 621-632.

Hillman, A.L., 2004. Corruption and public finance: An IMF perspective. European Journal of Political Economics 20, 1067-1077.

Hillman, A.L., Katz, E., 1987. Hierarchical structure and the social costs of bribes and transfers. Journal of Public Economics 34, 129-142.

Hillman, A.L., Schnytzer, A., 1986. Illegal economic activities and purges in a Soviet-type economy: A rent-seeking perspective. International Review of Law and Economics 6, 8799.

Hillman, A.L., Ursprung, H.W., 2000. Political Culture and economic decline. European Journal of Political Economy 16, 189-213.

Huntington, S., 1968. Political Order in Changing Societies. Yale University Press, New Haven, CT.

International Intellectual Property Alliance, 2006. Special 301, Special Mention, Sweden, Report Issued on February 13, 2006. Available at http://www.iipa.com/rbc/2006/2006SPEC301SWEDEN.pdf.

Jensen, M.C., 1988. The takeover controversy: Analysis and evidence. In: Coffee, J.C., Jr., Lowenstein, L., Rose-Ackerman, S. (Eds.), Knights, Raiders, and Targets, Oxford University Press, New York, NY, pp. 314-54.

Johnston, M., 1997. Public officials, private interests, and sustainable democracy: When politics and corruption meet. In: Elliott, K.A. (Ed.), Corruption and the Global Economy, Institute for International Economics, Washington, DC, pp. 61-82.

Jönsson, S., 1993. Editorial: Anecdotal evidence. Scandinavian Journal of Management 9, 8587.

Kaiser, P. (Ed.), Country Profile of the Republic of Georgia. Science Applications International Corporation, McLean, VA.

Klitgaard, R., 1988. Controlling Corruption. University of California Press, Berkeley, CA.

Kohler, H. (Ed.), 1968. Readings in Economics. Holt, Rinehart and Winston, Inc., New York, NY.

Kornai, J., 1979. Resources vs. demand-constrained systems. Econometrica 47, 801-819.

Kornai, J., 1990. The Road to a Free Economy: Shifting from a Socialist System, the Example of Hungary. W.W. Norton \& Company, New York, NY.

Lamsdorff, J., 1998. An empirical investigation of bribery in international trade. European Journal of Development Research 10, 40-59.

Lang, O., 1936. On the economic theory of socialism. Review of Economic Studies 4, 53-71.

Leff, N., 1964. Economic development through bureaucratic corruption. The American Behavioral Scientist 8, 8-14.

Levin, M., Satarov, G., 2000. Corruption and institutions in Russia. European Journal of Political Economics 16, 113-132.

Levy, D., Bergen, M., 1993. Simulating a multiproduct barter exchange economy. Economic Inquiry 31, 314-321.

Levy, D., Bergen, M., Dutta, S., Venable, R., 1997. The magnitude of menu costs: Direct evidence from large U.S. supermarket chains. Quarterly Journal of Economics 112, 791825.

Levy, D., Dutta, S., Bergen, M., 2002. Heterogeneity in price rigidity: Evidence from a case study using micro-level data. Journal of Money, Credit and Banking 34, 197-220.

Levy, D., Dutta, S., Bergen, M., Venable, R., 1998. Price adjustment at multiproduct retailers. 
Managerial and Decision Economics 19, 81-120.

Levy, D., Young, A.T., 2004. "The Real Thing": Nominal price rigidity of the nickel Coke, 1886-1959. Journal of Money, Credit and Banking 36, 765-799.

Lien, D., 1986. Note on competitive bribery games. Economics Letters 22, 337-341.

Loewenstein, G., Small, D.A., Strnad, J., 2007. Statistical, identifiable and iconic victims. In: McCaffery, E., Slemrod, J. (Eds.) Behavioral Public Finance: Toward a New Agenda. Russell Sage Publications, New York, forthcoming.

Ludwig, J., Kling, J.R., 2006. Is crime contagious? Industrial Relations Section, Working Paper No. 510, Princeton University.

Lui, F., 1985. Equilibrium queuing model of bribery. Journal of Political Economy 93, 760-781.

Lukka, K., Kasanen, E., 1995. The problem of generalizability: Anecdotes and evidence in accounting research. Accounting, Auditing and Accountability Journal 8, 71-90.

Marjit, S., Mukherjee, V., Mukherjee, A., 2000. Harassment, corruption and tax policy. European Journal of Political Economics 16, 75-94.

Mauro, P., 1995. Corruption and growth. Quarterly Journal of Economics 110, 681-712.

Mauro, P., 1997. The effects of corruption on growth, investment, and government expenditures: A cross-country analysis. In: Elliott, K. (Ed.), Corruption and the Global Economy, Institute for International Economics, Washington, DC, pp. 83-107.

McCloskey, D.N., 1998. If You Are So Smart: The Narrative of Economic Expertise. University of Chicago Press, Chicago, IL.

McCloskey, D.N., 1998. The Rhetoric of Economics, 2nd Edition. The University of Wisconsin Press, Madison, WI.

Méndez, F., Sepúlveda, F., 2006. Corruption, growth, and political regimes: Cross-country evidence. European Journal of Political Economics 22, 82-98.

Naylor, R.T., 1998. Corruption in the modern arms business: Terms from the Pentagon scandals. In: Jain, A. (Ed.), Economics of Corruption, Kluwer Academic Publishers, Boston, MA.

Paldam, M., 2002. The cross-country pattern of corruption: Economics, culture, and the seesaw dynamics. European Journal of Political Economics 18, 215-240.

Pascha, W., 1999. Corruption in Japan - an economist's perspective. Discussant's comments on "Shadow Politics - Political Corruption in Japan" made at the annual meeting of the Association for Asian Studies in Boston, March 14, 1999.

Radford, R.A., 1945. The economic organization of a P.O.W. camp. Economica 12, 189-201.

Reinikka, R., Svenssen, J., 2001. Explaining leakages of public funds. Policy Research Working Paper No. 2709, The World Bank, Washington, DC.

Reiter, S.A., Williams, P.F., 1997. Scientific conversation in financial economics. A manuscript presented at the 5th Interdisciplinary Perspectives on Accounting Conference, University of Manchester, July 7-9, 1997.

Rodrik, D., Rauch, J.E., 1997. Comments. In: Elliott, K.A. (Ed.), Corruption and the Global Economy, Institute for International Economics, Washington, DC, pp. 109-116.

Romer, C., Romer, D., 1994. Monetary policy matters. Journal of Monetary Economics 34, 75-88.

Rose-Ackerman, S., 1997. The political economy of corruption. In: Elliott, K.A. (Ed.), Corruption and the Global Economy, Institute for International Economics, Washington, DC, pp. 31-60.

Rotemberg, R., 1988. Rationing in centrally planned economies. Working Paper, Harvard Business School.

Shleifer, A., Vishny, R., 1992. Pervasive shortages under socialism. Rand Journal of Economics 23, 237-246.

Shleifer, A., Vishny, R., 1993. Corruption. Quarterly Journal of Economics 108, 599-617.

Simes, D.K., 1975. The Soviet parallel markets. Survey 21, 42-52.

Simis, K., 1977. The machinery of corruption in the Soviet Union. Survey 23, 35-55.

Simis, K., 1982. USSR: Secrets of a Corrupt Society. Dent, London. 
Small, D.A., Loewenstein, G., 2003. Helping $a$ victim or helping the victim: altruism and identifiability. Journal of Risk and Uncertainty 26, 5-16.

Tavartkiladze, L., 1998. Georgia Report for GEO Project. Georgia Greens Energy Group, Helio International Report, Paris.

Treisman, D., 2000. The causes of corruption: a cross-national study. Journal of Public Economics 76, 399-457.

Weitzman, M.L., 1977. Is the price system or rationing more effective in getting a commodity to those who need it most? Bell Journal of Economics 8, 517-524.

Williams, R. (Ed.), 2000. The Politics of Corruption, Vol. 1, Explaining Corruption. Edward Elgar, Cheltenham, UK.

Williams, R., Theobald, R. (Eds.), 2000. The Politics of Corruption, Vol. 2, Corruption in the Developing World. Edward Elgar, Cheltenham, UK.

Williams, R., Moran, J., Flanary, R. (Eds.), 2000. The Politics of Corruption, Vol. 3, Corruption in the Developed World, Edward Elgar, Cheltenham, UK.

Williams, R., Doig, A. (Eds.), 2000. The Politics of Corruption, Vol. 4, Controlling Corruption, Edward Elgar, Cheltenham, UK.

Zbaracki, M., Ritson, M., Levy, D., Dutta, S., Bergen, M., 2004. Managerial and customer costs of price adjustment: Direct evidence from industrial markets. Review of Economics and Statistics 86, 514-533.

Zbaracki, M., Bergen, M., Levy, D., 2006. The anatomy of a price cut: Discovering organizational sources of the costs of price adjustment. Bar-Ilan University and Emory University Working Paper. 